\title{
Deteksi Pemakaian Helm Proyek Dengan Metode Convolutional Neural Network
}

\author{
Bambang Widodo, Teknologi Informasi Institut Sains dan Teknologi Terpadu Surabaya(ISTTS), \\ Hendrawan Armanto, Informatika Institut Sains dan Teknologi Terpadu Surabaya(ISTTS), \\ Endang Setyati, Teknologi Informasi Institut Sains dan Teknologi Terpadu Surabaya(ISTTS).
}

\begin{abstract}
Abstrak- Penggunaan helm proyek pada pekerjaan dengan resiko kecelakaan tinggi seperti pekerjaan konstruksi seringkali diabaikan oleh pekerja, sehingga apabila terjadi kecelakaan kerja yang tidak diinginkan seperti kejatuhan benda keras dari atas atau terjadi benturan keras pada kepala akan berakibat fatal bagi pekerja tersebut. Penelitian ini bertujuan untuk mendeteksi pemakaian helm proyek oleh pekerja konstruksi pada citra. Metode yang digunakan pada penelitian ini adalah Convolutional Neural Network YOLO. Sistem terdiri dari tiga proses utama yaitu proses pre processing, proses training dan proses deteksi. Proses pre processing adalah melakukan resize dan anotasi labeling pada citra dataset. Selanjutnya adalah proses training pada dataset dengan menggunakan transfer learning YOLOv2. Pada proses deteksi digunakan 4 buah anchor box pada setiap grid pada citra, hasil dari mencari nilai ukuran bounding box yang memiliki IOU terbaik dengan melakukan proses clustering pada dataset training dan validasi yang terdapat bounding box menggunakan algoritma K-Mean clustering. Algoritma Intersection Over Union (IOU) dan Non Max Suppression (NMS) digunakan agar bounding box prediksi yang dibuat presisi dengan objek yang berhasil dideteksi dan untuk menghilangkan multideteksi pada objek yang sama. Proses deteksi pada sistem ini melakukan lokalisasi dan klasifikasi dengan sekali langkah proses sehingga hasil dari proses deteksi ini adalah orang menggunakan helm proyek dan orang tidak menggunakan helm proyek. Pengujian sistem deteksi dilakukan secara individu maupun kelompok maksimal 5 orang dengan F1-score yang diperoleh sebesar 0,79 .
\end{abstract}

\section{Kata Kunci-Bounding Box, CNN, Helm Proyek, YOLO}

\section{PENDAHULUAN}

Helm adalah alat pelindung kepala yang berfungsi melindungi kepala dari benturan sehingga kepala tidak mengalami cedera. Beberapa kegiatan manusia yang menggunakan helm untuk melindungi kepala diantaranya

Bambang Widodo, Departemen Teknologi Informasi, Institut Sains dan Teknologi Terpadu Surabaya, Surabaya, Jawa Timur, Indonesia (e-mail: bamb.inside@gmail.com)

Hendrawan Armanto, Departemen Informatika, Institut Sains dan Teknologi Terpadu Surabaya, Surabaya, Jawa Timur, Indonesia (e-mail: hendrawan@stts.edu)

Endang Setyati, Departemen Teknologi Informasi, Institut Sains dan Teknologi Terpadu Surabaya, Surabaya, Jawa Timur, Indonesia (e-mail: endang@stts.edu) adalah mengendarai kendaraan bermotor roda dua, melakukan pekerjaan konstruksi, beberapa kegiatan olah raga dan lain sebagainya.

Untuk pekerjaan konstruksi para pekerja diwajibkan menggunakan alat keselamatan kerja, helm proyek adalah salah satu alat keselamatan kerja yang wajib digunakan, hal tersebut sebagai salah satu tujuan penting dan harus dipatuhi oleh pekerja konstruksi dalam K3 (Keselamatan dan Kesehatan Kerja). Akan tetapi masih banyak pekerja konstruksi yang tidak menggunakan helm proyek pada saat bekerja. Mereka menggunakan helm yang sudah disediakan hanya apabila ada pengawasan dari supervisor atau penyelia, akan tetapi bila supervisor tersebut tidak berada di lokasi, sering diantara para pekerja melepas helmnya, padahal hal tersebut sangat berbahaya dan bisa berakibat fatal bila terjadi suatu insiden yang tidak diinginkan seperti kejatuhan benda keras dari atas atau terjadi benturan keras yang mengakibatkan cidera pada kepala.

Pada penelitian ini menggunakan metode Convolutional Neural Network (CNN) YOLO. Convolutional Neural Network (CNN) YOLO adalah salah satu metode Deep learning (DL) dan dapat digunakan untuk mendeteksi dan mengenali suatu objek pada sebuah citra sehingga diharapkan dapat mendeteksi pekerja yang menggunakan helm proyek dan yang tidak menggunakan helm proyek.

\section{TINJAUAN PUSTAKA}

Pada tahun 2017 Jimit Mistry, Aashish K. Misraa, Meenu Agarwal, Ayushi Vyas, Vishal M. Chudasama dan Kishor P. Upla telah melakukan penelitian untuk melakukan deteksi orang menggunakan helm dan orang tidak menggunakan helm pada pengendara sepeda motor beserta ekstraksi plat nomor menggunakan Convolutional Neural Network (CNN)[1]. Penelitian ini diterbitkan di Jurnal IEEE 2017. Peneliti menggunakan dua model YOLOv2[2], salah satunya untuk mendeteksi pengendara sepeda motor yang memakai helm dan yang tidak memakai helm. Model YOLOv2 pertama dilatih dengan dataset $\mathrm{COCO}[3]$ yang mendeteksi jumlah kelas dalam suatu gambar. Gambar kelas orang yang telah dipotong dari YOLOv2 pertama digunakan sebagai input untuk model YOLOv2 kedua yang selanjutnya dilatih dengan dataset helm. Dataset helm ini terdiri dari gambar helm saja.

Untuk deteksi orang menggunakan dataset $\mathrm{COCO}$, untuk tahap kedua deteksi helm menggunakan dataset 3054 gambar helm. Untuk tahap testing dataset gambar menggunakan helm dan tidak menggunakan helm diunduh dari ImageNet[4]. Dataset testing adalah 409 gambar memakai helm dan 403 gambar tidak memakai helm. Hasil akurasi dari penelitian ini adalah $94,7 \%$ pada 2500 iterasi. 
Pada tahun 2015 Xiaogang Chen, Pengxu Wei, Wei Ke, Qixiang Ye dan Jianbin Jiao melakukan penelitian deteksi pejalan kaki dengan Deep Convolutional Neural Network (Deep-CNN)[5] yang diterbitkan di Springer International Publishing Switzerland. Dalam penelitian ini, Aggregated Channel Features (ACF) dan Deep Convolutional Neural Networks (DCNN) digunakan untuk mendeteksi pejalan kaki dengan fitur yang sangat kompleks secara efisien dan efektif. ACF digunakan untuk menghasilkan kandidat windows pejalan kaki dan DCNN digunakan untuk klasifikasi. Eksperimen yang dilakukan memiliki peforma yang baik untuk dataset INRIA[6].

Pada tahun 2016 Sugianto dari Institut Sains dan Teknologi Terpadu Surabaya melakukan penelitian deteksi alat pelindung kepala (helm) menggunakan metode Haar Cascade Classifier[7]. Sistem terdiri dari dua proses utama yaitu proses training data dan proses deteksi. Pada proses training terdapat empat proses, yaitu haar-like feature, citra integral, ada-boost dan cascade classifier. Haar-like feature merupakan kumpulan fitur khusus yang mempresentasikan kepala, wajah dan helm. Citra integral adalah cara cepat menghitung haar feature, sedangkan ada-boost adalah pembobotan secara statistik nilai-nilai fitur yang didapat dan di-filter menggunakan cascade classifier.

Dataset yang digunakan adalah 1026 dataset positif dan 1627 dataaset negatif, dataset positif berupa citra manusia dengan menggunakan helm dan dataset negatif adalah citra yang bukan manusia menggunakan helm (citra background dan pemandangan). Hasil uji coba pada 20 frame video dengan 7 skenario adalah akurasi sebesar 92\% untuk uji coba individu dan akurasi sebesar $71 \%$ untuk uji coba kelompok.

Selanjutnya adalah beberapa teori penunjang yang digunakan dalam penelitian ini.

\section{A. Artificial Neural Network (ANN)}

Artificial Neural Network (ANN) merupakan suatu model komputasi paralel yang meniru fungsi dari sistem jaringan syaraf biologi otak manusia. Dalam otak manusia terdiri dari milyaran neuron yang saling berhubungan. Hubungan ini disebut dengan Synapses. Komponen neuron terdiri dari satu inti sel yang akan melakukan pemrosesan informasi, satu akson (axon) dan minimal satu dendrit. Informasi yang masuk akan diterima oleh dendrit. Selain itu, dendrit juga menyertasi akson sebagai keluaran dari suatu pemrosesan informasi.. Struktur dasar dari Jaringan Syaraf Tiruan terdiri dari 3 jenis layer utama, yaitu input, hidden, dan output layer [8]

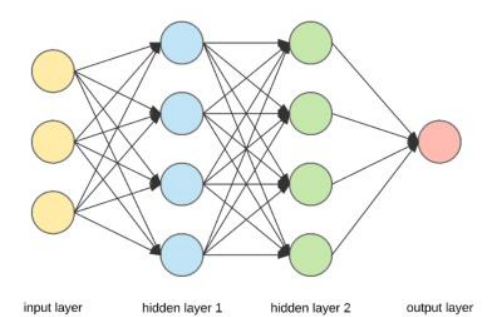

Gambar.1. Struktur Artificial Neural Network (ANN)

\section{B. Convolutional Neural Network (CNN)}

Convolutional Neural Network (CNN)[9] telah memiliki terobosan hasil yang baik selama dekade terakhir di berbagai bidang yang terkait dengan pengenalan pola; dari pemrosesan gambar hingga ke pengenalan suara. Aspek yang paling bermanfaat dari $\mathrm{CNN}$ adalah mengurangi jumlah parameter dalam Artificial Neural Network (ANN). Prestasi ini telah mendorong peneliti dan pengembang untuk melakukan pendekatan model yang lebih besar untuk menyelesaikan tugas-tugas kompleks, yang tidak mungkin dilakukan dengan ANN klasik. Aspek penting lain dari $\mathrm{CNN}$, adalah untuk memperoleh fitur abstrak saat input merambat ke lapisan yang lebih dalam. Misalnya, dalam klasifikasi gambar, tepi citra mungkin terdeteksi di lapisan pertama, dan kemudian bentuk lebih sederhana di lapisan kedua, dan kemudian fitur dengan tingkat yang lebih tinggi seperti wajah di lapisan selanjutnya.

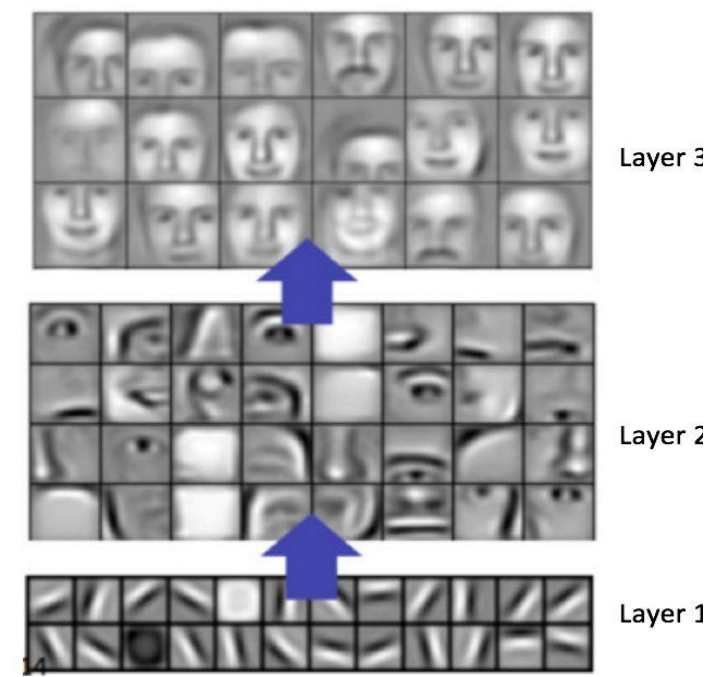

Gambar.2. Learned Fiture Dari Sebuah CNN

\section{You Only Look Once (YOLO)}

You Only Look Once atau YOLO[10], akan membagi inputan citra menjadi grid berukuran $\mathrm{S} \times \mathrm{S}$, dimana nilai $\mathrm{S}$ adalah 7 dengan input gambar berukuran 448 x 448. Jika titik tengah koordinat pada GT (Ground Truth) suatu objek berada di dalam grid, maka grid tersebut bertanggung jawab untuk mendeteksi suatu objek. Setiap grid sel memprediksi B bounding box dan confidence score untuk kotak tersebut[11]. Confidence score ini mencerminkan seberapa yakin model tersebut bahwa di dalam bounding box berisi objek dan juga nilai akurasi prediksinya. Untuk mendapatkan bounding box prediksi, akan dilakukan konvolusi dari inputan citra, sehingga hasil akhirnya akan mendapat ukuran bounding box sebesar $\mathrm{S} \times \mathrm{S} \times(\mathrm{B} * 5+\mathrm{C})$ dimana B adalah banyaknya bounding box (umumnya 2) dalam 1 grid dan $\mathrm{C}$ adalah banyaknya kelas yang dapat diklasifikasi. Nilai B dikalikan dengan 5 karena sebuah bounding box memiliki 5 nilai yang perlu disimpan, koordinat $\mathrm{x}$, koordinat $\mathrm{y}$, lebar (width), tinggi (height), dan confidence score (nilai probabilitas bounding box yang bersangkutan memiliki sebuah objek).

Untuk semua atribut pada bounding box akan dilakukan normalisasi sehingga nilainya menjadi antara 0 hingga 1 . Koordinat $\mathrm{x}$ dan $\mathrm{y}$ akan dinormalisasi menyesuaikan titik kiri atas dari grid yang bersangkutan. Dan tinggi dan lebar akan dinormalisasi sesuai dengan ukuran gambar (lebar dan tinggi). Nilai koordinat $\mathrm{x}$ dan $\mathrm{y}$ pada sebuah bounding box pada setiap grid merupakan titik tengah grid yang bersangkutans. Ilustrasi YOLO dapat dilihat pada Gambar 3. 


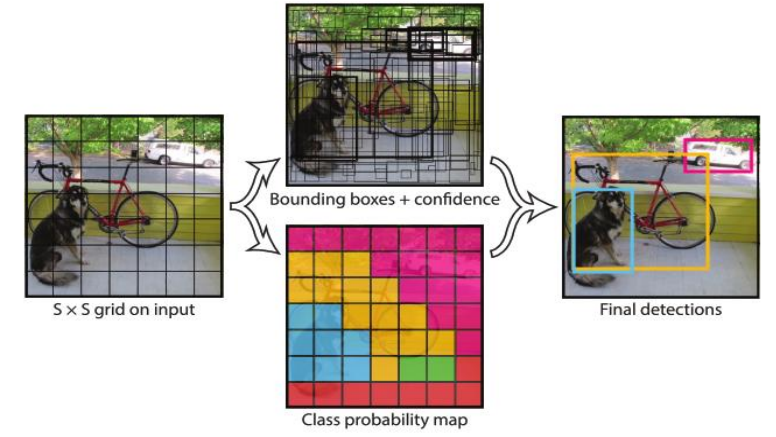

Gambar.3. Model YOLO

\section{Intersection Over Union (IOU)}

Intersection over Union (IOU) merupakan metode evaluasi untuk mengukur akurasi deteksi objek terhadap suatu dataset[12]. IOU membutuhkan 2 area yang akan diiris dan digabung, 2 area tersebut adalah area ground-truth bounding box yang merupakan bounding box aktual dan area yang dideteksi dari model yang dibuat[13]. Setiap bounding box terdiri dari 5 prediksi: $\mathrm{x}, \mathrm{y}, \mathrm{w}, \mathrm{h}$, dan confidence. Koordinat $(\mathrm{x} ; \mathrm{y})$ adalah pusat grid sel pada bounding box. Lebar dan tinggi ( $\mathrm{w}$ dan $\mathrm{h}$ ) adalah ukuran dari citra. Prediksi confidence adalah IOU (Intersection Over Union) antara predicted bounding box dan ground trouth bounding box. Setiap grid sel juga memprediksi probabilitas kelas bersyarat $C, \operatorname{Pr}\left(\mathrm{Class}_{i} \mid \mathrm{Object}\right)$. Probabilitas ini dikondisikan pada sel grid yang berisi objek. Sistem hanya memprediksi satu set probabilitas kelas pada setiap grid sel, terlepas dari jumlah $B$ box. Pada saat pengujian sistem mengalikan probabilitas kelas bersyarat dan box confidence prediction, yang memberi nilai confidence pada kelas untuk setiap bounding box.

$$
\text { IoU }=\frac{\text { Irisan }}{\text { Gabungan }} \frac{\text { Irisan }}{\text { Gred. }}
$$

Gambar.4. Intersection Over Union (IOU)

\section{E. Non Max Suppression (NMS)}

Non Max Suppression (NMS)[14] digunakan untuk menyeleksi bounding box yang muncul berlebihan pada objek yang sama dengan membandingkan nilai confidence masing-masing bounding box, hanya nilai confidence yang paling tinggi (maksimal) yang akan dipertahankan.

Algoritma Non Max Suppression :

1. Pilih proposal dengan skor confidence tertinggi, hapus dari $B$ dan tambahkan ke dalam daftar proposal final $D$. (Awalnya $D$ kosong).

2. Sekarang bandingkan proposal ini dengan semua proposal - hitung IOU (Intersection over Union) proposal ini dengan setiap proposal lainnya. Jika IOU lebih besar dari ambang $N$, hapus proposal tersebut dari $B$.
3. Sekali lagi ambil proposal dengan confidence tertinggi dari proposal yang tersisa di $B$ dan hapus dari $B$ dan tambahkan ke $D$.

4. Sekali lagi hitung IOU proposal ini dengan semua proposal di $B$ dan hilangkan kotak yang memiliki IOU tinggi dari ambang batas.

5. Proses ini diulangi sampai tidak ada lagi proposal yang tersisa di $B$.

Dibawah ini adalah pseudo-code Non Max Suppression :

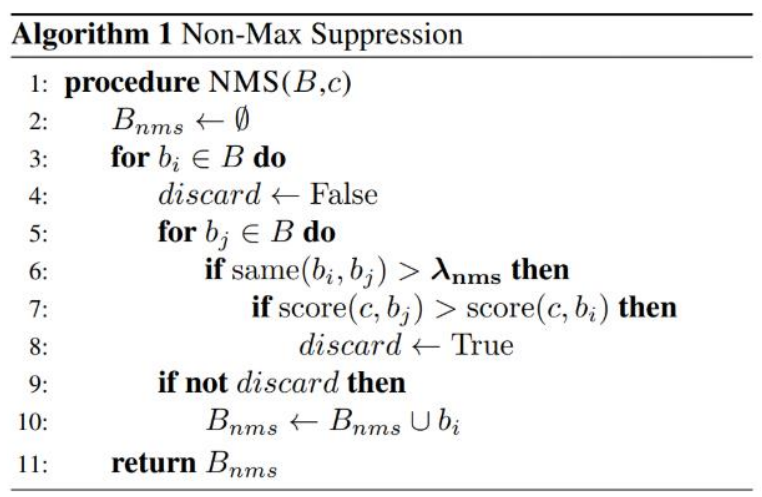

Gambar.5. Pseudo-code Non Max Suppression

\section{F. Akurasi}

Perhitungan tingkat akurasi menggunakan precision, recall dan F1-score[15]. Precision adalah tingkat ketepatan antara informasi yang diminta oleh pengguna dengan jawaban yang diberikan oleh sistem. Recall adalah tingkat keberhasilan sistem dalam menemukan sebuah informasi. F1-score adalah ukuran akurasi sebuah uji coba.

Precision $=\frac{\text { true positive }}{\text { true positive }+ \text { false positive }}$

Recall $=\frac{\text { true positive }}{\text { true positive }+ \text { false negative }}$

F1-score $=2 \times \frac{\text { precision } x \text { recall }}{\text { precision }+ \text { recall }}$

- True Positive adalah jumlah objek yang berhasil terdeteksi

- False positive adalah jumlah objek yang terdeteksi namun bukan objek yang benar

- False negative adalah jumlah objek yang tidak terdeteksi tetapi objek yang benar

\section{PERANCANGAN}

Pada Bab Perancangan ini akan dibahas mengenai desain alur kerja dari sistem dan algoritma yang akan digunakan.

A. Alur Sistem

Alur sistem yang digunakan pada penelitian ini ditunjukkan pada gambar 6. Proses awal adalah resize dan labeling citra lalu melakukan training dengan transfer learning menggunakan pre trained model YOLOv2 menghasilkan bobot baru. Selanjutnya bobot baru digunakan untuk melakukan proses deteksi orang memakai helm proyek dan orang tidak memakai helm proyek pada citra uji coba. 


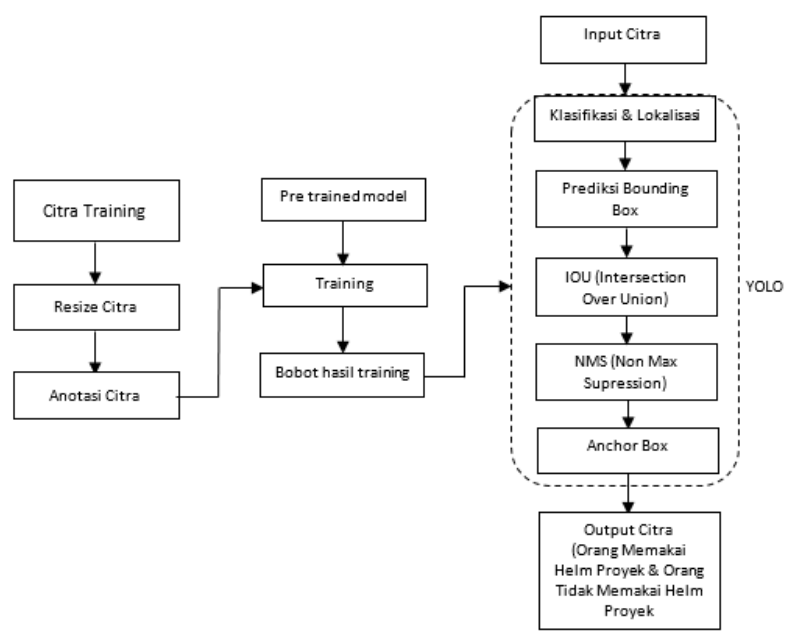

Gambar.6. Alur Sistem

\section{B. Pre Processing}

Pada tahap pre processing semua citra dataset dirubah ukurannya menjadi 448 x 448 piksel serta dilakukan proses labeling atau anotasi dengan menggunakan program labelImg.

\section{Training}

Dataset hasil anotasi selanjutnya digunakan untuk proses training dengan YOLOv2 menggunakan transfer learning untuk mendapatkan bobot baru, yaitu dengan menggunakan bobot pre trained model yang sudah dilatih untuk mengenali objek baru. Pre trained model yang digunakan adalah bobot YOLOv2 dijalankan pada Google Colaboratory, epoch dan batch size pada proses training 100 dan 64, sedangkan bobot baru yang dihasilkan akan digunakan untuk mendeteksi orang memakai helm proyek dan orang tidak memakai helm proyek.

\section{Klasifikasi dan Lokalisasi}

Klasifikasi citra adalah pengkategorian suatu citra ke dalam suatu kategori atau kelas tertentu sedangkan lokalisasi citra adalah menentukan letak atau posisi dari suatu objek didalam citra tersebut dengan bounding box. Deteksi objek pada citra adalah penggabungan dari klasifikasi dan lokalisasi beberapa objek dalam satu citra. Untuk klasifikasi dan lokalisasi citra hanya bisa untuk satu objek sedangkan pada deteksi objek pada citra bisa digunakan untuk lebih dari satu objek. Pada algoritma YOLO, dilakukan proses klasifikasi terlebih dahulu baru proses lokalisasi dengan menambahkan bounding box pada objek kelas yang terdeteksi dalam sekali proses deteksi.

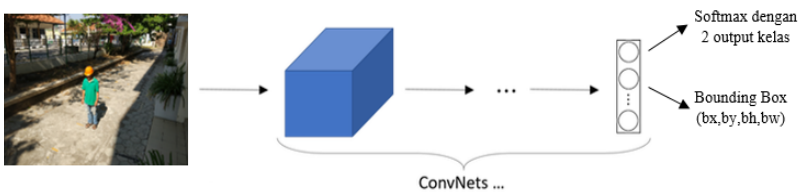

Gambar.7. Proses Deteksi Objek Dengan 2 Kelas

\section{E. Prediksi Bounding Box}

Untuk menentukan bounding box dari sebuah grid pada citra, maka didefinisikan koordinat sebuah grid pada citra adalah $(0,0)$ terletak di atas kiri dan $(1,1)$ terletak di bawah kanan. Pada Gambar 7 titik tengah bounding box berupa titik berwarna biru, disini mewakili bx dan by. Nilai bx dan by antara 0 sampai dengan 1 dari sebuah grid, untuk nilai bx dicari dengan cara mengukur dari titik $(0,0)$ kearah kanan sampai dengan tepi kanan grid pada titik $(1,1)$. Disini nilai $\mathrm{bx}=0,2$. Sedangkan nilai by dicari dengan cara mengukur dari titik $(0,0)$ kearah bawah sampai dengan tepi bawah grid pada titik $(1,1)$. Nilai by $=0,5$. Untuk nilai bw adalah lebar bounding box dibandingkan dengan lebar grid, tinggi dan lebar grid didefinisikan 1 jadi nilai bw $=0,3$. Nilai bh adalah tinggi bounding box dibandingkan dengan tinggi grid, nilai bh $=1,1$ karena tinggi dari bounding box melebihi tinggi dari grid. Untuk nilai bx dan by adalah antara 0 sampai dengan 1, sedangkan untuk nilai bh dan bw bisa jadi lebih besar dari 1 atau melebihi ukuran tinggi dan lebar dari grid.

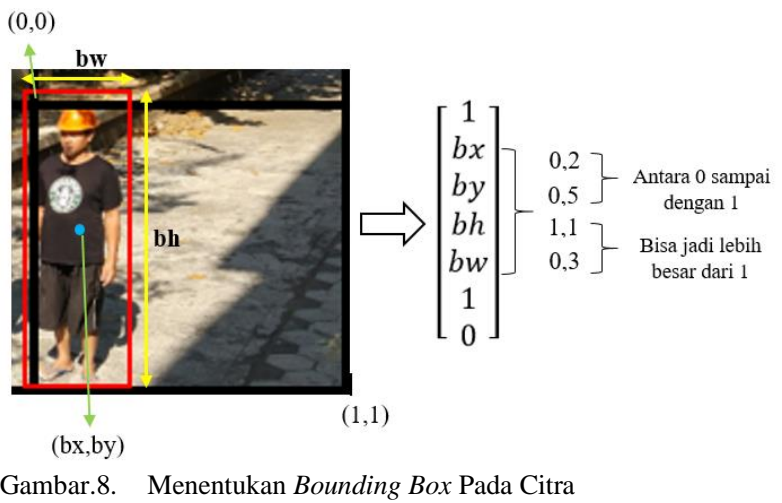

\section{F. Intersection Over Union (IOU)}

IOU dihitung dari luas area irisan dibagi luas gabungan dari bounding box ground truth (warna merah) dan bounding box prediksi (warna biru). Bila perbandingan rasio atau IOU antara bounding box prediksi dan bounding box ground truth adalah 1, maka dikatakan IOU sangat sempurna karena tujuan dari bounding box prediksi adalah sama atau mendekati bounding box ground truth. Untuk nilai hasil IOU sama atau lebih besar dari 0,5 bisa dikatakan bounding box prediksi sudah cukup tepat dalam membuat bounding box pada objek. Penentuan nilai threshold akan berpengaruh pada hasil lokalisasi objek pada citra. Bila threshold terlalu tinggi maka bisa berakibat jumlah objek yang terdeteksi lebih sedikit dari jumlah objek yang sebenarnya, sedangkan bila threshold terlalu rendah bisa berakibat satu objek dideteksi oleh beberapa bounding box.

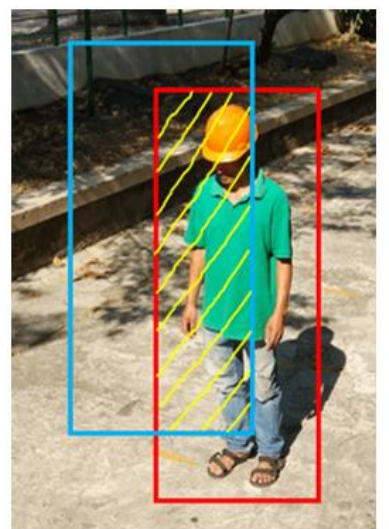

(a)

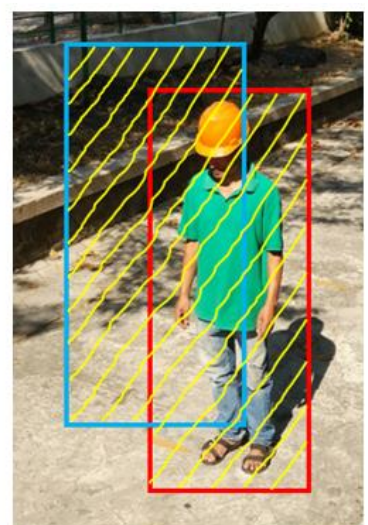

(b)
Gambar.9. Area Irisan Bounding Box Ground Truth dan Bounding Box Prediksi (a), Area Gabungan Bounding Box Ground Truth dan Bounding Box Prediksi (b)

G. Non Max Suppression (NMS) 
Salah satu kendala dalam deteksi objek adalah ada kemungkinan multiple deteksi pada satu objek. Satu objek tidak dideteksi sebagai satu objek tapi dideteksi berkali-kali dan dikenali sebagai lebih dari satu objek sehingga akurasi dari deteksi objek akan rendah. Untuk mengatasi permasalahan tersebut maka digunakan Non Max Suppression (NMS). Non Max Suppression (NMS) bekerja dengan cara membersihkan bounding box prediksi yang mempunyai nilai probabilitas terendah dan mengambil satu bounding box prediksi yang mempunyai nilai probabilitas tertinggi. Bila threshold Non Max Suppression ditentukan 0,6 maka setelah melalui proses Non Max Suppression akan diambil bounding box dengan nilai probabilitas tertinggi yaitu 0,8 untuk objek orang tidak memakai helm proyek (bounding box warna merah) dan 0,9 untuk objek orang memakai helm proyek (bounding box warna kuning).

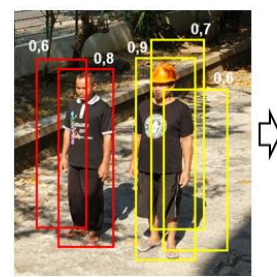

Prediksi Awal

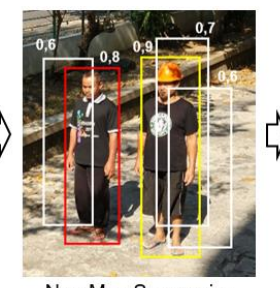

Non Max Supression

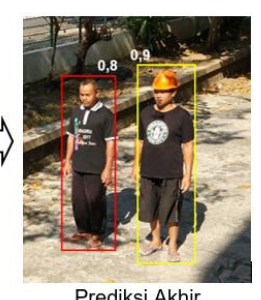

Prediksi Akhir
Gambar.10. Proses Non Max Suppression Pada Bounding Box

\section{H. Anchor Box}

Sebuah grid pada citra, hanya dapat mendeteksi satu objek. Bila dalam satu grid terdapat dua buah objek atau lebih, maka dapat digunakan anchor box. Pada penelitian ini menggunakan 4 buah anchor box, hasil dari mencari nilai ukuran bounding box yang memiliki IOU terbaik dengan melakukan proses clustering pada dataset training dan validasi yang terdapat bounding box menggunakan algoritma K-Mean clustering[16].

TABEL I

\begin{tabular}{cccc}
\multicolumn{4}{c}{ UKURAN 4 BUAH ANCHOR BOX } \\
\hline \hline \multirow{2}{*}{ No } & Lebar & Tinggi & Ukuran \\
\hline 1 & 0,06505013 & 0,24317773 & Sangat Kecil \\
2 & 0,10062081 & 0,45632851 & Kecil \\
3 & 0,29744874 & 0,75714696 & Besar \\
4 & 0,16295355 & 0,6445702 & Sedang \\
\hline \hline
\end{tabular}

\section{PENGUJIAN DAN ANALISIS}

\section{A. Dataset}

Dataset yang digunakan dalam penelitian ini adalah citra orang memakai helm proyek (diambil dari dataset VOC2028) sebanyak 1500 citra yang dibagi menjadi 1200 citra untuk data pelatihan dan 300 citra untuk data validasi serta dataset orang tidak memakai helm proyek (diambil dari dataset INRIA) sebanyak 1500 citra yang dibagi menjadi 1200 citra untuk data pelatihan dan 300 citra untuk data validasi. Posisi tubuh pada dataset orang memakai helm proyek dan dataset orang tidak memakai helm proyek bervariasi.

DATASET

\begin{tabular}{lccc}
\hline \hline & $\begin{array}{c}\text { Orang } \\
\text { Memakai } \\
\text { Helm Proyek }\end{array}$ & $\begin{array}{c}\text { Orang Tidak } \\
\text { memakai Helm } \\
\text { Proyek }\end{array}$ & Total \\
\hline Dataset Training & 1200 & 1200 & 2400 \\
Dataset Validasi & 300 & 300 & 600 \\
\hline \hline
\end{tabular}

- Citra Orang Memakai Helm Proyek

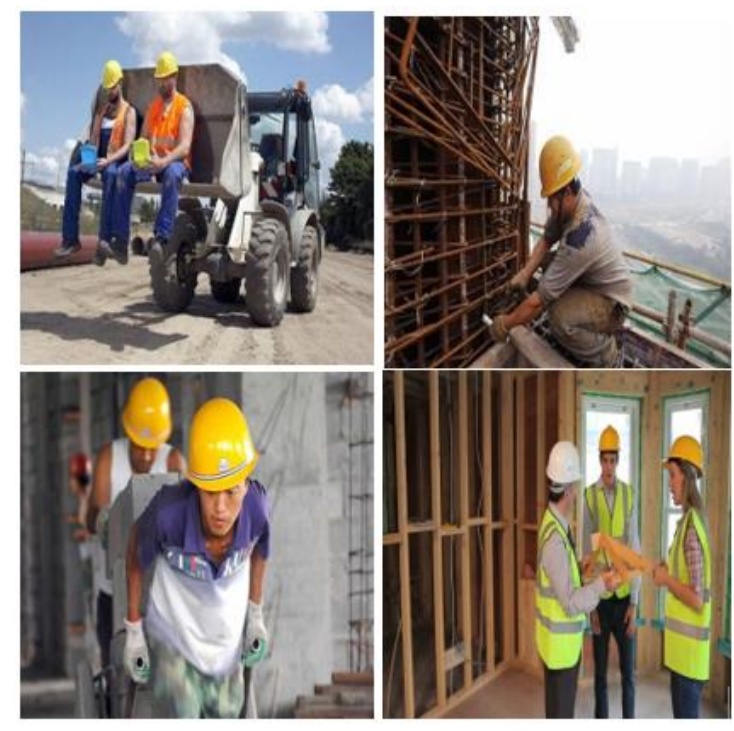

Gambar.11. Citra Orang Memakai Helm Proyek

- Citra Orang Tidak Memakai Helm Proyek
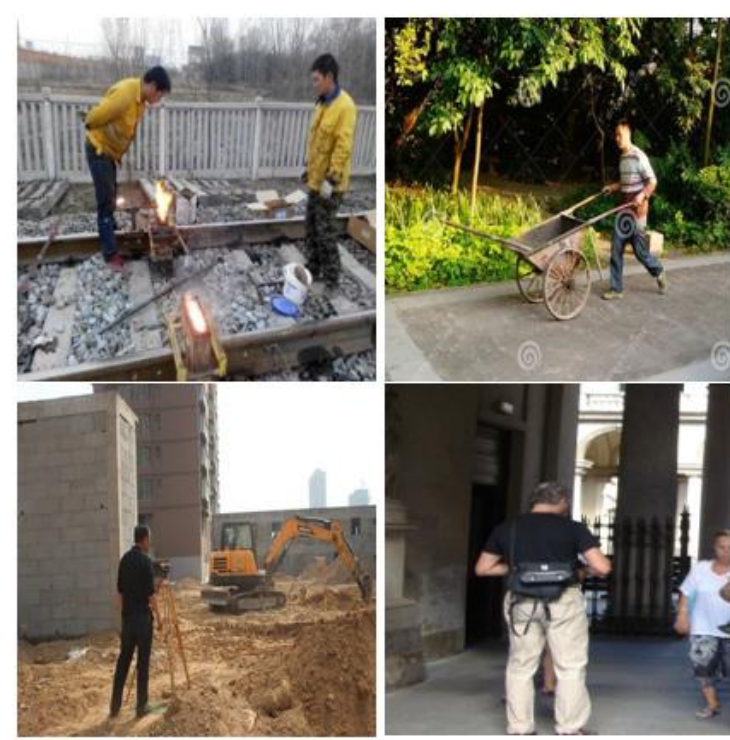

Gambar.12. Citra Orang Tidak Memakai Helm Proyek

\section{B. Pengujian}

Uji coba dilakukan pada data uji sejumlah 90 citra yang dibagi menjadi 9 skenario yaitu 1 orang memakai helm proyek, 1 orang tidak memakai helm proyek, 1 orang memakai helm proyek 1 orang memakai topi baseball, 1 orang memakai helm proyek 1 orang tidak memakai helm proyek, 1 orang memakai helm proyek 1 orang memakai helm halfface, 2 orang memakai helm proyek 1 orang memakai topi baseball 1 orang memakai helm halfface 1 orang tidak memakai helm proyek, 2 orang memakai helm proyek ditenteng, 3 orang memakai helm proyek dan 3 orang memakai helm proyek 2 orang tidak memakai helm proyek.

Jarak objek dengan kamera adalah 1 - 10 meter. Citra diambil dengan kamera yang diletakkan didepan pekerja yang berjalan kedepan, posisi kamera dipojok dengan ketinggian 2,5 meter diatas tanah. Threshold objek adalah 0,3 dan threshold IOU adalah 0,3.

Pada Gambar 13 untuk uji coba dengan kondisi 1 orang memakai helm proyek pada jarak objek dengan kamera 4 
meter, sistem berhasil mendeteksi dengan benar, nilai prediksi yang dihasilkan adalah 0,789. Sedangkan pada Gambar 14 terdapat 2 objek dengan 2 kelas yang berbeda, yaitu 1 orang memakai helm proyek dan 1 orang tidak memakai helm proyek pada jarak objek dengan kamera 1 meter. Pada kondisi ini objek lebih sulit untuk dideteksi dibandingkan dengan kondisi pada Gambar 13 yang hanya memiliki 1 objek pada sebuah citra. Pada hasil uji coba ini sistem berhasil mendeteksi dengan benar, nilai prediksi yang dihasilkan adalah 0,741 (orang memakai helm proyek) dan 0,376 (orang tidak memakai helm proyek).

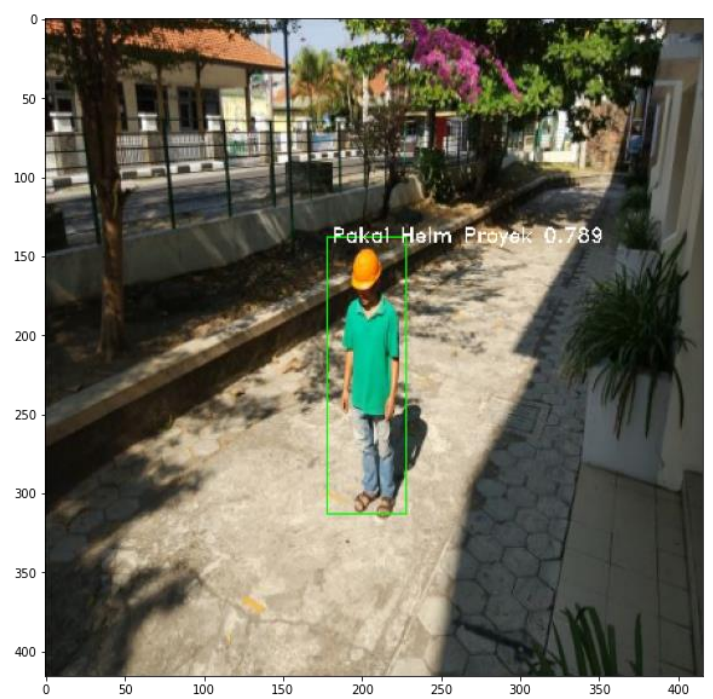

Gambar.13. Hasil Uji Coba 1 Orang Memakai Helm Proyek

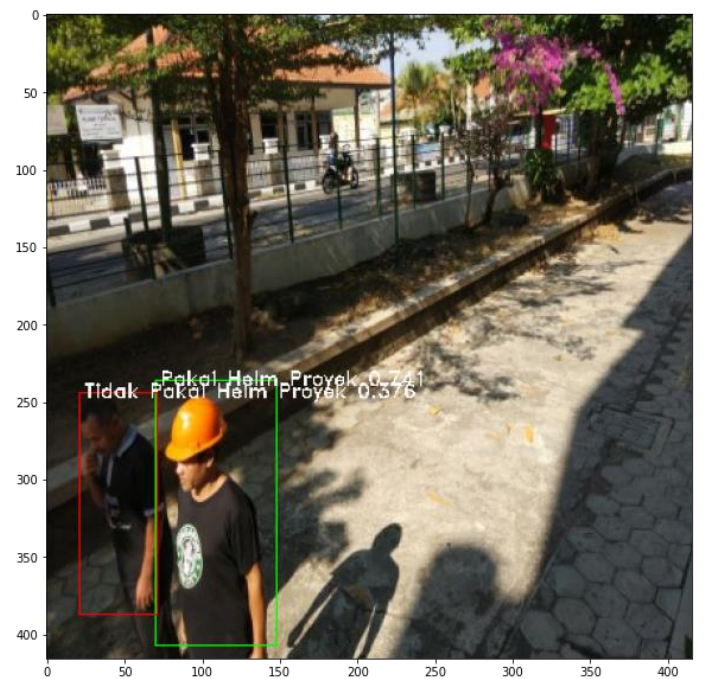

Gambar.14. Hasil Uji Coba 1 Orang Memakai Helm Proyek 1 Orang

Untuk keseluruhan hasil uji coba ditunjukkan pada Tabel III. Dalam 9 skenario yang telah dijelaskan sebelumnya, pekerja dikondisikan dengan berbagai macam situasi, seperti jumlah pekerja paling sedikit adalah 1 orang dan paling banyak adalah 5 orang. Selain itu penutup kepala tidak hanya helm proyek, tapi digunakan juga topi baseball dan helm halfface, hal ini bertujuan untuk menguji sistem dalam mendeteksi penutup kepala selain helm proyek.
TABEL III

DATA HASIL PENGUJIAN

\begin{tabular}{|c|c|c|c|c|}
\hline $\begin{array}{c}\text { Jarak Objek } \\
\text { Dengan } \\
\text { Kamera }(\mathrm{m}) \\
\end{array}$ & Kondisi & Precision & Recall & $\begin{array}{l}\text { F1- } \\
\text { Score }\end{array}$ \\
\hline $1-10$ & $\begin{array}{l}1 \text { orang memakai } \\
\text { helm proyek }\end{array}$ & 1 & 1 & 1 \\
\hline $1-10$ & $\begin{array}{l}1 \text { orang tidak } \\
\text { memakai helm } \\
\text { proyek }\end{array}$ & 0,90 & 0,90 & 0,90 \\
\hline $1-10$ & $\begin{array}{l}1 \text { orang memakai } \\
\text { helm proyek } 1 \\
\text { orang memakai } \\
\text { topi baseball }\end{array}$ & 0,50 & 0,90 & 0,63 \\
\hline $1-10$ & $\begin{array}{l}1 \text { orang memakai } \\
\text { helm proyek } 1 \\
\text { tidak memakai } \\
\text { helm proyek }\end{array}$ & 0,65 & 0,90 & 0,70 \\
\hline $1-10$ & $\begin{array}{l}1 \text { orang memakai } \\
\text { helm proyek } 1 \\
\text { tidak memakai } \\
\text { helm halfface }\end{array}$ & 0,90 & 0,87 & 0,88 \\
\hline $1-10$ & $\begin{array}{c}2 \text { orang memakai } \\
\text { helm proyek } 1 \\
\text { memakai topi } \\
\text { baseball } 1 \\
\text { memakai helm } \\
\text { halfface } 1 \text { tidak } \\
\text { memakai helm } \\
\text { proyek }\end{array}$ & 0,82 & 0,57 & 0,65 \\
\hline $1-10$ & $\begin{array}{l}2 \text { orang helm } \\
\text { ditenteng }\end{array}$ & 0,80 & 0,80 & 0,80 \\
\hline $1-10$ & $\begin{array}{l}3 \text { orang pakai } \\
\text { helm proyek }\end{array}$ & 1 & 0,87 & 0,92 \\
\hline $1-10$ & $\begin{array}{l}3 \text { orang memakai } \\
\text { helm proyek } 2 \\
\text { tidak memakai } \\
\text { helm proyek }\end{array}$ & 0,80 & 0,55 & 0,63 \\
\hline & Rata-rata & 0,82 & 0,82 & 0,79 \\
\hline
\end{tabular}

\section{KESIMPULAN}

Dari hasil pengujian pada Tabel III terhadap 90 citra yang dibagi menjadi 9 skenario yang dilakukan diperoleh $F 1$ score sebesar 0,79. Hasil F1-score untuk jumlah pekerja yang berkelompok (lebih dari 1 orang pekerja) lebih rendah dibandingkan dengan jumlah pekerja yang individu karena seringkali tubuh pekerja berdempetan, tertutup satu dengan yang lain, sehingga sistem kesulitan untuk mendeteksi dengan benar. Dengan hasil ini sistem dapat membantu pengawas untuk memastikan para pekerja menggunakan helm proyek di lokasi pekerjaan dengan hasil yang optimal pada pekerja individu (tidak berkelompok).

\section{DAFTAR PUSTAKA}

J. Mistry, A. K. Misraa, M. Agarwal, A. Vyas, V. M. Chudasama, and K. P. Upla, "An automatic detection of helmeted and nonhelmeted motorcyclist with license plate extraction using convolutional neural network," in 2017 seventh international conference on image processing theory, tools and applications (IPTA), 2017, pp. 1-6.

[2] J. Redmon and A. Farhadi, "YOLO9000: better, faster, stronger," in Proceedings of the IEEE conference on computer vision and pattern recognition, 2017, pp. 7263-7271.

[3] T.-Y. Lin et al., "Microsoft coco: Common objects in context," in 
European conference on computer vision, 2014, pp. 740-755.

[4] A. Krizhevsky, I. Sutskever, and G. E. Hinton, "ImageNet classification with deep convolutional neural networks," Commun. ACM, vol. 60, no. 6, pp. 84-90, 2017.

[5] X. Chen, P. Wei, W. Ke, Q. Ye, and J. Jiao, "Pedestrian detection with deep convolutional neural network," in Asian Conference on Computer Vision, 2014, pp. 354-365.

[6] N. Dalal and B. Triggs, "Histograms of oriented gradients for human detection," in 2005 IEEE computer society conference on computer vision and pattern recognition (CVPR'05), 2005, vol. 1, pp. 886-893.

[7] S. Sugianto, E. Setyati, and H. Armanto, "Deteksi Alat Pelindung Kepala (Helm) Menggunakan Metode Haar Cascade Classifier," Joutica, vol. 4, no. 1, pp. 232-236, 2019.

[8] A. Hermawan, "Jaringan Saraf Tiruan: Teori dan Aplikasi," 2006.

[9] S. Albawi, T. A. Mohammed, and S. Al-Zawi, "Understanding of a convolutional neural network," in 2017 International Conference on Engineering and Technology (ICET), 2017, pp. 16.

[10] J. Redmon, S. Divvala, R. Girshick, and A. Farhadi, "You only look once: Unified, real-time object detection," in Proceedings of the IEEE conference on computer vision and pattern recognition, 2016, pp. 779-788.

[11] M. Menegaz, "Understanding YOLO," 2017. https://hackernoon.com/understanding-yolo-f5a74bbc7967.

[12] A. Rosebrock, "Intersection over Union (IoU) for object detection," l\ \ilnea].[Consultado 20 enero 2020]. Dispon. en https//www. pyimagesearch. com/2016/11/07/intersection-overunion-iou-forobject-detection, 2016.

[13] A. Kamal, "Yolo, yolov2 and yolov3: All you want to know," Mediu. Seach date, 2019.

[14] K. Sambasivarao, "Non-maximum suppression (nms)," Online unter https://towardsdatascience. com/non-maximumsuppression-nms-93ce178e177c [Stand 16.10. 2019], 2019.

[15] M. Septian and K. Kunci, "DETEKSI WAJAH MENGGUNAKAN METODE VIOLA JONES PADA GRAPHICS PROCESSING UNIT FACE DETECTION USING VIOLA JONES METHOD ON GRAPHICS,’ Ilmu Komputer, Tek. Inf., 2014.

[16] V.Yadav, "Generating Anchor boxes for Yolo-like network for vehicle detection using KITTI dataset," 2017. https://vivekyadav.medium.com/part-1-generating-anchor-boxes-for-yololike-network-for-vehicle-detection-using-kitti-datasetb2fe033e5807. 